\section{Research Article}

(C) 2021 Diab et.al..

This is an open access article licensed under the Creative Commons Attribution-NonCommercial 4.o International License (https://creativecommons.org/licenses/by-nc/4.o/)

\title{
The Impact of Client Size and Financial Performance on Audit Opinion: Evidence from a Developing Market
}

\author{
Ahmed A. Diab ${ }^{1,2}$ \\ Samir I. Abdelazim ${ }^{2,3}$ \\ Aref M. Eissa ${ }^{3,4}$ \\ Eid Mahmoud Abozaid ${ }^{2,5}$ \\ Mona Mohamed Elshaabany5 \\ ${ }^{1}$ College of Business Administration, Prince Sultan University, \\ P.O.Box No. 66833 Rafha Street, Riyadh 11586, Saudi Arabia; \\ ${ }^{2}$ Faculty of Commerce, Beni-Suef University, Qism Bani Sweif, \\ Bani Sweif, Beni Suef Governorate, Egypt \\ ${ }^{3}$ College of Business Administration, Majmaah University, \\ Industrial Area, Al Majma'ah 15341, Saudi Arabia; \\ ${ }^{4}$ Faculty of Commerce, Cairo University, Cairo University Rd, 12613, Egypt \\ ${ }^{5}$ College of Business, Jouf University, Sakaka, Saudi Arabia;
}

DOI: https://doi.org/10.36941/ajis-2021-0020

\section{Abstract}

This research investigates the effect of audit client size and its financial performance on audit opinion in the Egyptian audit market. A few studies have investigated the association between these factors in the audit context, especially in African developing countries. Data are manually collected from the annual financial reports of firms registered in the Egyptian Stock Market, focusing on a sample of EGX 70 from 2012 to 2016 , and binary logistic regression is used in data analysis. We found that the company size is insignificantly, positively, related to a qualified, rather than an unqualified, type of audit opinion. In contrast, the client's financial performance has a significant but negative relationship with the qualified type of audit opinion. This study provides insights for managers and investors in developing countries to understand and perceive audit opinions in these contexts.

Keywords: Audit opinion, company size, financial performance, Egypt

\section{Introduction}

This study investigates if/how client size and financial performance affect audit opinion by bringing evidence from a developing context. It is observed that very few studies have concentrated on the relationship between client size and audit opinion (Carcello et al., 200o) and the impact of client financial performance on audit opinion (Vichitsarawong and Pornupatham, 2015). However, previous 
studies mainly focused on the impact of other related factors such as earnings persistence (e.g., Vichitsarawong and Pornupatham, 2015); financial distress (e.g., Ruiz-Barbadillo et al., 2004); and earnings management practices (e.g., Johl et al., 2007; Xu et al., 2018). A few related studies are conducted in emerging markets (e.g., Li et al., 2008 in China; Johl et al., 2007 in Malaysia; Jaggi and Tsui, 1999 in Hong Kong; Vichitsarawong and Pornupatham 2015 in Thailand). Yet, very few related studies are conducted in African audit markets such as Egypt (e.g., Afify, 2009).

Developing countries are worthy of a particular investigation. The audit field in these settings is reported as less concentrated than the case in developed markets because of its emerging nature (Li et al., 2008). The Egyptian audit market, particularly, has some unique characteristics that motivated us to conduct this study. For example, Egypt is one of the few contexts that allow both single audits, joint audits, and dual audits (El-Dyasty, 2017). Further, Egypt's audit practices are not very mature, as the case in most African emerging markets, compared to the situation in advanced and stable countries such as the USA and the UK (Kabir et al., 2012).

Regarding the Egyptian audit market development, following the Company Law 159/1981, all listed companies in Egypt became required to hold separate appropriate accounting books from those of their shareholders and have an independent audit at each year-end (Mohamed and Habib, 2013). Besides, the Capital Market Law 95/1992, and its subsequent modifications, required all listed companies in Egypt to make their annual reports according to local Accounting Standards. If these standards are not present, companies must follow International Accounting Standards (Wahdan et al., 2012). In 2009, the Auditors Oversight Board was established to investigate local auditors' performance and assess their competence and conformity with auditing standards (EFSA, 2012). To practice the audit profession in Egypt, all public accountants should be certified by General Register for the Accountants and Auditors (CAO, 2012). Regarding the structure of the audit market in Egypt, governmental-owned firms, and firms in which governmental institutions own $25 \%$ or more of their stocks should be audited by the Egyptian Accountability State Authority (ASA) (Khlif and Samaha, 2014). In total, the ASA audits approximately $22 \%$ of firms registered in the Egyptian Stock Exchange (EGX), and the remaining firms are audited by private auditors (El-Dyasty, 2017). El-Dyasty (2017) reported that Big 4 auditors hold approximately $35 \%$ of the market; private local auditors hold $31 \%$; and other foreign audit firms (excluding Big 4) hold approximately 34\% (AboZaid et al., 2020). Thus, Big 4 and ASA are the key audit firms in the Egyptian market.

This study is informed by the agency theory. This is because, being motivated by enhancing their own benefits (rather than shareholders' interests), corporate managers might hide important information from owners or provide them with business information that is different from the core of business transactions (Daoud et al., 2014). This indicates the importance of audit quality and external audit opinion and the dynamics affecting this process. This study focuses on some corporate-related characteristics to examine whether they affect the audit opinion likely to be issued by the auditor.

The present study contributes to the literature by investigating if specific corporate-related factors (e.g., corporate size and financial performance) influence the audit opinion, an issue that is rarely examined in the literature. We found that the company size is positively associated with a qualified type of audit opinion. Financial performance, in contrast, is negatively associated with a qualified type of audit opinion. This study also contributes to the literature by presenting evidence from a rarely investigated context-an African emerging audit market. This provides important insights for shareholders and regulators in this context about the audit profession's nature and the variables influencing it.

The paper is structured as follows. Section 2 introduces the literature review and the hypotheses examined in this study. Section 3 outlines the research methods. Section 4 provides data analyses and findings. Finally, section 5 discusses the findings and concludes the paper.

\section{Literature Review and Hypotheses Development}

Several studies have investigated the factors that are likely to determine the type of audit report that 
the auditor will issue. Most of these studies focus on the impact of auditor-related factors on audit opinion. For example, Craswell et al. (2002) and Ireland (2003) examined the relationship between qualified opinions and auditor independence. They reported that larger audit companies are more cautious in issuing unqualified audit opinions. Li et al. (2008) documented a relationship between the audit company size and issuing qualified audit opinions in China. This is the case in contexts that are not yet being dominated by a small number of big audit companies and audit fields in which clients are partially government-owned enterprises. Further, Breesch and Branson (2009) suggested that women auditors can better detect errors and fraud in financial statements than male auditors. This is because they suggested, women auditors are more risk-averse than male auditors. DeFond and Lennox (2011) found that clients of exiting auditors get better audit quality from successive audit companies, as measured by a higher probability of issuing going-concern opinions.

Another strand in the literature investigated the impact of client-related characteristics on audit opinion. Here, a large portion of these studies argues that auditors are likely to modify their opinions to decrease litigation risk exposure (Blay, 2005; Joe, 2003). In this regard, Kaplan and Williams (2013) found that the audit company's ex-ante litigation risk is positively associated with going concern opinions. Relatedly, Joe (2003) revealed that the adverse press coverage convoys to audit companies a high probability of a client's failure, contributing to qualifying auditors' opinions (see also McKeow et al., 1991). Further, Bryan et al. (2000) found a positive relationship between issuing a going concern audit opinion and a firm successfully recovering from bankruptcy.

Other studies investigated the impact of audit client's earnings management practices on audit opinion. For example, Johl et al. (2007) examined if earnings management practices affected audit opinion during the Asian Economic Crisis in Malaysia. They found that Big 5 audit firms are more likely to modify their opinions than non-Big five audit firms when higher abnormal accruals are detected. In a recent study, $\mathrm{Xu}$ et al. (2018) found a significant and positive relationship between real earnings management practices and the possibility of getting a going concern audit opinion in companies facing financial difficulties. This suggests that the client's abnormal business activity can affect auditor reporting conservatism. Our study contributes to the previously mentioned studies by focusing on the impact of other client-related characteristics (such as company size and its financial performance) on audit opinion, as discussed below.

\subsection{Client size and audit opinion}

The relationship between client size and audit opinion is rarely examined in the literature. Karjalainen (2011) noted that audit quality is more critical for larger firms. Tsipouridou and Spathis (2014) found that companies' size in Greece is among the determining factors of receiving a going-concern opinion. Carcello and Nagy (2004) found that big U.S. client companies can have higher bargaining power, and hence, they can convince the auditor to submit to aggressive accounting.

Especially in the case of least-developed countries (LDCs) such as Egypt, it is not always feasible for auditors to possess the industry expertise required to investigate larger clients. Larger clients work in a more complex business environment and operate in more than one industry, which is more likely to impact audit opinion (see Carcello and Nagy, 2004). Based on this argument, we believe that corporate size will be negatively related to the type of audit opinion, and hence larger companies are expected to receive qualified opinions: opinion.

$H_{1}$ : Larger companies are more expected to get a qualified opinion, rather than an unqualified

\subsection{Financial performance and audit opinion}

Some studies in the literature identified the factors that lead to receiving going concern opinion. In this regard, the managerial ability is reported as another determinant factor of issuing going concern opinions (Citron and Taffler, 1992). For example, Krishnan and Wang (2015) found a negative 
association between managerial ability and the probability of getting a going concern audit opinion. They argue that higher managerial ability is related to better earnings quality and a lower probability of corporate failure.

Most studies in the literature reported a negative association between financial performance and modified or adverse opinions. Citron and Taffler (1992) reported a positive association between the probability of UK companies' financial problems and receiving a going concern qualification decision. Mutchler et al. (1997) found a positive association between U.S. companies' debt default and the possibility of issuing a qualified opinion. Ruiz-Barbadillo et al. (2004) reported a positive association between audit quality and the likelihood of receiving a going-concern opinion by U.S. financially distressed companies. They also reported a relationship between the high cost of debt capital and the possibility of receiving qualified audit opinions. Lopez et al. (2009) linked the possibility of receiving an adverse opinion over financial reporting in the U.S. to financial factors such as the high cost of capital and the low sustainability of profitability. Xie et al. (2010) indicated that high-profit firms could have the power to convince auditors to issue favourable opinions. Tsipouridou and Spathis (2014) noted that profitability is one of the determinants of receiving a going-concern audit opinion in Greece. Vichitsarawong and Pornupatham (2015) found that Thai companies with lower earnings persistence receive qualified, rather than unqualified, audit opinions. Gallizo and Saladrigues (2016) found that Spanish companies reporting losses and being audited by smaller auditors are more likely to receive a going concern audit opinion. Mareque et al. (2019) found that auditor tenure and client financial performance are related to receiving a favourable audit opinion. In contrast, financial losses achieved during the previous year, among other factors, are related to unfavourable opinions. Considering these studies, we formulated our second hypothesis as follows:

$\mathrm{H}_{2}$ : Clients with higher financial performance are highly expected to receive an unqualified, rather than a qualified, audit opinion.

\section{Research design}

\subsection{Sample selection}

The study sample comprises the Egyptian registered firms in the EGX 70 during the period 2012 - 2016. After excluding financial companies, companies presenting their financial statements in foreign currency, and missing observations, our final sample consisted of 53 companies with 257 observations (Table 1).

Table 1: The sample companies classified by industry

\begin{tabular}{|l|c|c|}
\hline Sector & Number of companies & \% out of total \\
\hline Tourism & 4 & $7.5 \%$ \\
\hline Cement and construction & 8 & $15 \%$ \\
\hline Food & 13 & $\mathbf{2 4 . 6 \%}$ \\
\hline chemicals & 3 & 5.7 \\
\hline Investment, Contracting and development & 8 & 15 \\
\hline Textile & 7 & 13.2 \\
\hline Transportation & 6 & 11.3 \\
\hline Technology and communication & $\mathbf{1}$ & $\mathbf{2} \%$ \\
\hline minerals & 3 & 5.7 \\
\hline Total & 53 & $\mathbf{1 0 0} \%$ \\
\hline
\end{tabular}

Data are manually collected from the annual financial reports of the sample companies. SPSS (version 20) is used for data analysis, where various tests are conducted, including the goodness of fit, determinant coefficient, and logistic regression. 


\subsection{Research model and variables measurement}

We use the following model to test the study hypotheses:

Opinion $_{i t}=\alpha+\beta_{1}$ Size $_{i t}+\beta_{2} R O A_{i t}+\beta_{3}$ leverage $_{i t}+\beta_{4}$ Big $_{i t}+B_{5}$ Loss $_{i t}+$ B6 Specializ $_{i t}+$ fixed industry effect $_{i t}+$ fixed year effect ${ }_{i t}+\varepsilon_{i t}$

Audit opinion (Opinion) is the dependent variable. Following Vichitsarawong and Pornupatham (2015), we define audit opinion as a dummy variable coded as 1 if auditors issue a qualified opinion and o otherwise. The study has two independent variables: client size (Size); and financial performance. We measure client size using the natural log of total assets (see Vichitsarawong and Pornupatham, 2015), and return on assets (ROA) is used as the measurement of client financial performance (see Allgood and Farrell, 2003).

Our study controls for the company leverage (leverage). This is because companies with more leverage are more likely to face financial difficulties (Ohlson, 1980), influencing the type of audit opinion (Bryan et al., 2000; Joe, 2003). Leverage is measured by dividing total debt over total assets. We also control for auditor size (Big), which is defined here as a dummy variable coded as 1 if the company is audited by one of the Big 4 audit firms and o otherwise. Big 4 audit firms are likely to present better audit quality than non-Big 4 audit firms (Becker et al., 1998; DeAngelo, 1981; Fan and Wong, 2005). Several studies linked the audit opinion type to the audit firm size (e.g., Carcello et al., 200o; Gallizo and Saladrigues, 2016; Mareque et al., 2019). Besides, following Atwood et al. (2011) and Vichitsarawong and Pornupatham (2015), we include loss as a control variable. Loss is measured as a dummy variable coded as 1 if the company incurred loss in the current year and o otherwise. This is important to account for variances or the drop-in client performance. We also control for auditor specialization (Specializ). Previous studies reported positive effects of auditor specialization on audit quality (e.g., Lim and Tan, 2010; Rusmin and Evans, 2017). We measure auditor specialization as a dummy variable coded as 1 if the auditor is auditing $20 \%$ or more of the companies working in a particular business sector and o otherwise (Kato et al., 2016). Finally, the study controls for industry and year effects using industry and year dummies. Table 2 below provides a summary of the variables' measurement.

Table 2: Variables measurement

\begin{tabular}{|l|l|}
\hline Variables & Definitions \\
\hline Opinion & A dummy variable coded as 1 if the auditor reports a qualified type of opinion in year $t$, and o otherwise \\
\hline Client Size & Log of total assets \\
\hline ROA & Net income over total assets \\
\hline Financial leverage & Total debts over total assets \\
\hline Auditor size & A dummy variable coded as 1 if a company is audited by one of the Big 4 auditors, and o otherwise \\
\hline Loss & A dummy variable coded as 1 if the company incurred loss in the current year, and o otherwise \\
\hline Auditor Specialization & A dummy variable coded as 1 if the audit firm is specialized in the industry of the client, and o otherwise \\
\hline
\end{tabular}

\section{Results and Analysis}

\subsection{Descriptive statistics}

This research's descriptive statistics present the minimum and maximum values, the mean, and the standard deviation (SD), and the research variables' frequency distribution.

The audit opinion. Table 3 below presents the frequency distribution of the audit opinion (qualified and unqualified) each year. Throughout the study period, we observed that the number of companies receiving an unqualified opinion is 206 out of the 257 sample companies. This means that $80 \%$ of the sample companies receive an unqualified audit opinion, and only $20 \%$ are receiving a qualified audit opinion. 
Table 3: The frequency distribution of the audit opinion

\begin{tabular}{|l|c|c|c|}
\hline \multicolumn{4}{|c|}{ Audit Opinion } \\
\hline Year & Unqualified & Qualified & Total \\
\hline 2012 & & & \\
Count & 40 & 11 & 51 \\
\% of total & 15.7 & 4.3 & 20 \\
\hline 2013 & & & \\
Count & 43 & 10 & 53 \\
\% of total & 16.7 & 3.9 & 20.6 \\
\hline 2014 & 43 & 10 & \\
Count & 16.7 & 3.9 & 53 \\
\% of total & 41 & 12 & \\
\hline 2015 & 16 & 4.6 & 53 \\
Count & & & 20.6 \\
\% of total & 39 & 8 & 47 \\
\hline 2016 & 15.2 & 3 & 18.2 \\
Count & & & \\
\% of total & 206 & 51 & 257 \\
\hline Total & 80 & 20 & 100 \\
Count & & & \\
\% of total & & & \\
\hline
\end{tabular}

Table 4: The descriptive statistics of company size, return of assets and leverage

\begin{tabular}{|l|c|c|c|}
\hline Audit opinion & Company Size & ROA & Leverage \\
\hline Unqualified & \multicolumn{3}{|c|}{} \\
\hline Mean & 20.46 & 4.89 & 39.26 \\
\hline $\mathrm{n}$ & 206 & 206 & 206 \\
\hline SD & 1.59 & 7.17 & 21.92 \\
\hline Minimum & 17 & -11.10 & 0 \\
\hline Maximum & 24 & 19.65 & 96 \\
\hline Qualified & \multicolumn{3}{|l|}{} \\
\hline Mean & 20.20 & -1.43 & 33.96 \\
\hline $\mathrm{n}$ & 51 & 51 & 51 \\
\hline SD & 1.17 & 5.58 & 22.11 \\
\hline Minimum & 17 & -11.10 & 2 \\
\hline Maximum & 22 & 14.91 & 86 \\
\hline Total & \multicolumn{3}{|l|}{} \\
\hline Mean & 20.41 & 3.63 & 38.21 \\
\hline n & 257 & 257 & 257 \\
\hline SD & 1.52 & 7.32 & 22.02 \\
\hline Minimum & 17 & -11.10 & 0 \\
\hline Maximum & 24 & 19.65 & 96 \\
\hline
\end{tabular}

Company size. As indicated in Table 4, the average company size is 20.41 , with an SD of 1.52, and the minimum and maximum values of company size are 17 and 24, respectively. The company size in the case of companies receiving an unqualified opinion is 20.46, on average, with an SD of 1.59, and the minimum and the maximum values of the company size are 17 and 24 . In contrast, the company size in companies receiving a qualified opinion is 20 , on average, with an SD of 1.17, and the minimum and maximum values of company size are 17 and 22, respectively.

ROA. As indicated in Table 4, the average companies' ROA is 3.63, with an SD of 7.32, and the minimum and the maximum values of ROA are -11.10 and 19.65, respectively. The ROA in companies receiving an unqualified opinion is 4.89 , on average, with an SD of 7.17 , and the minimum and the 
maximum values of ROA are -11.10, and the maximum of 19.65. In contrast, the ROA in companies receiving a qualified opinion is -1.43 , on average, with an $\mathrm{SD}$ of 5.58 , and the minimum and maximum values of ROA are -11.10 and 14.91 , respectively.

Leverage. As observed in Table 4, the average companies' leverage is 38.21, with an SD of 22.02, and the minimum and the maximum values of leverage are o and 96, respectively. The leverage level of the companies getting an unqualified opinion is 39.26, on average, with an SD of 21.92, and the minimum and the maximum values of leverage are o and 96, respectively. However, the leverage level of the companies getting a qualified opinion is 33.96 with an SD of 22.11 and the minimum and the maximum values of leverage are two and 86 , respectively.

Auditor size. Table 5 indicates that, throughout the study period, the number of companies audited by Big 4 auditors is 123 companies out of 257 or $47.9 \%$. In contrast, the number of companies audited by non-Big 4 auditors is 134 or $52.1 \%$ of the sample companies' total number.

Auditor specialization. Table 5 indicates that, throughout the study period, the number of audit companies that are specialised in the client business is 131 out of 257 or $51 \%$. In contrast, the number of audit companies that are not specialised in the client business is 126 or $49 \%$ of the sample companies' total number.

Loss. Table 5 indicates that the number of sample companies that incurred loss in the current year is 68 out of 257 or $26.5 \%$. In contrast, the number of companies that achieved profit is 189 or $73.5 \%$ of the sample companies' total number.

Table 5: The frequency distribution of the auditor size, Specialize, Loss

\begin{tabular}{|l|l|c|c|c|}
\hline \multicolumn{2}{|c|}{ Auditor Size } & Big4 & Non Big4 & Total \\
\cline { 2 - 5 } & Frequencies & 123 & 134 & 257 \\
\cline { 2 - 5 } & Percent & 47.9 & 52.1 & 100 \\
\hline \multirow{2}{*}{ Audit firm Specialization } & Frequencies & 131 & No & Total \\
\cline { 2 - 5 } & Percent & 51 & 49 & 257 \\
\hline \multirow{2}{*}{ Loss } & & Yes & No & 100 \\
\cline { 2 - 5 } & Frequencies & 68 & 189 & 257 \\
\cline { 2 - 5 } & Percent & 26.5 & 73.5 & 100 \\
\hline
\end{tabular}

\subsection{Model analysis and hypotheses test}

Logistic regression analysis. We used the logistic regression analysis method to test the study hypotheses because the research's dependent variable is binary.

Goodness of fit. To evaluate the feasibility of the investigated model, a goodness of fit test is used. We found that the chi-square is 2.026 , with a significance level of 0.980 , i.e., more than 0.05 . This indicates that there is no difference between the prediction of the model and the value of the observation results, which concludes that the model is feasible and acceptable.

The determinant coefficient. The determinant coefficient revealed that the value of cox \& Snell $\mathrm{R}$ square is .311, and the value of Nagelkerke $R_{2}$ is .493. This indicates that independent and control variables (i.e., Size, ROA, Leverage, Big, Loss, and Specializ) could affect the dependent variable (Audit opinion) by $49 \%$. In contrast, other variables beyond those investigated in this study affect the dependent variable by $5_{1} \%$.

The classification test. The classification test (table 6) is conducted to assure the accuracy of the logistic regression model. 
Table 6: Classification test

\begin{tabular}{|l|l|c|c|c|}
\hline \multicolumn{3}{|l|}{ Predicted } \\
\hline Observed & unqualified & qualified & Percentage correct \\
\hline Step 1 Audit opinion & unqualified & 199 & 7 & 96.6 \\
\hline & qualified & 25 & 26 & 51 \\
\hline Overall percentage & & & 87.5 \\
\hline
\end{tabular}

The table indicates that out of the 206 companies receiving an unqualified opinion, 199 companies, or $96.6 \%$, can be accurately predicted by the logistic regression model. In comparison, the model cannot accurately predict seven companies. Out of the 51 companies receiving a qualified opinion, 26 companies, or $51 \%$, can be accurately predicted by the logistic regression model, and the model cannot accurately predict 25 companies. This finding indicates that out of the 257 sample companies, 225 companies, or $87.5 \%$, can be accurately predicted by the logistic regression model.

Hypotheses test. The hypothesis test is conducted using the logistic regression at a significance level $(\alpha)$ of $5 \%$. The hypotheses are acceptable if the significance value is less than $5 \%$; otherwise, they will be rejected.

Table 7: The logistic regression test

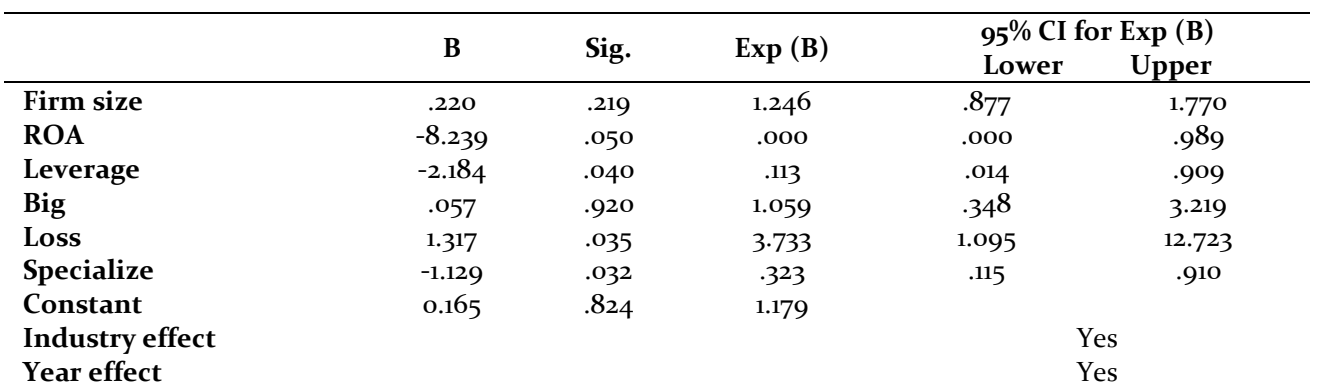

Table 7 indicates that firm size has a significance level of 0.2 (more than $\alpha$ ), ROA has a significance level of 0.05 , leverage has a significance level of 0.04 (less than $\alpha$ ), audit firm size has a significance level of 0.9 (more than $\alpha$ ), Loss has a significance level of 0.03 , and auditor specialization has a significance level of 0.03 (less than $\alpha$ ). Based on the hypotheses test, the logistic regression model can be attained as follows:

Opinion $=0.165+.220 \mathrm{X}_{1}-8.239 \mathrm{X}_{2}-2.184 \mathrm{X}_{3}-.057 \mathrm{X}_{4}+1.317 \mathrm{X}_{5-1.129} \mathrm{X}_{6}$

\section{Discussion and Conclusion}

This research examines the impact of corporate characteristics on audit opinion in a developing context. We found that the client's financial performance has a significant but negative relationship with qualified opinions. This agrees with the idea that high-profit firms can have the power to convince auditors to issue favourable opinions; solicit auditors who will issue a favourable opinion (see Xie et al., 2010); and hide misstatements from auditors (see Kumari and Pattanayak, 2014). This finding supports studies in the literature that reported a positive association between lower financial performance or losses and modified types of audit opinions. For example, Ruiz-Barbadillo et al. (2004) reported a positive association between audit quality and the possibility of receiving a going-concern opinion by financially distressed companies. Lopez et al. (2009) found a relationship between an adverse audit opinion and lower earnings sustainability. Vichitsarawong and Pornupatham (2015) found that Thai companies with lower earnings persistence receive qualified, rather than unqualified, 
audit opinions. Gallizo and Saladrigues (2016) reported that registering losses is positively associated with issuing a going concern audit opinion by Spanish companies. Mareque et al. (2019) show that ROA is among the factors that increase the likelihood of issuing a favourable opinion. In contrast, losses during the previous year, Mareque et al. (2019) found, contributed to increasing the likelihood of issuing an unfavourable opinion in the present year (see also Tsipouridou and Spathis, 2014).

Regarding the impact of corporate size, it is found to be insignificantly, positively, related to a qualified (rather than an unqualified) type of audit opinion. This finding is different from some studies in the literature, such as Tsipouridou and Charalambos Spathis (2014), who found that company size is a significant factor influencing the issuance of a going concern opinion in Greece. In this context, Siregar and Utama (2008) argue that larger companies, because of their substantial number of and complex transactions, may be more willing to hide some information from auditors and engage in earning smoothing practices, which increases the possibility of issuing a qualified type of audit opinion. This is considered important for managers of these companies to show their principals an indication of improved performance. Hence, they can maintain their positions, get advanced in jobs, and receive their promised incentives. The finding is also inconsistent with Carcello and Nagy (2004), who found that bigger companies in the United States are expected to receive favourable opinions. This is because, they argue, bigger companies have more bargaining power, and hence, they are in a better position to convince the auditor to acquiesce to aggressive accounting. Further, they argue that bigger companies work in multiple sectors, and hence auditors will be required to have greater industry experience to understand their expected complicated operations fully. This, in turn, they argue, increases the possibility of undetected misstatements in financial statements, and hence the likelihood of receiving unqualified opinions will increase (Carcello and Nagy, 2004).

Regarding the impact of control variables, we found that the leverage has a significant but negative relationship with a qualified type of audit opinion. This is consistent with the idea that, with high financial leverage, the client may be more willing to solicit auditors who issue favourable audit opinions or exercise pressures over auditors to do that (see Yasar et al., 2015). This finding may be specific to the case of LDCs, as this is different from other studies in the literature such as Mareque et al. (2019), who found that high financial leverage contributed to increasing the probability of receiving an unfavourable opinion (see also Bryan et al., 2000; Joe, 2003). Auditor size is found to have an insignificant relationship with audit opinion. This finding supports Citron and Taffler (1992), who reported no difference between smaller and larger audit companies in issuing going concern opinions in the United Kingdom. However, our finding is different from Mareque et al. (2019), who reported that hiring "Big 4" auditors contributed to increasing the possibility of issuing an unfavourable opinion (see also Carcello et al., 200o; Gallizo and Saladrigues, 2016). Client losses are found to have a significant positive relationship with a qualified opinion. This finding supports Mareque et al. (2019), who noted that the client past financial difficulties contributed to increasing the probability of receiving an unfavourable opinion (see also Gallizo and Saladrigues, 2016). Finally, we found that the auditor specialisation has a significant negative association with qualified audit opinions (cf. Lim and Tan, 2010; Rusmin and Evans, 2017).

This study contributes to the few studies in the literature that investigate the effect of corporaterelated characteristics on audit opinion -that is, the majority of studies in the literature concentrated on the impact of auditor (rather than the client) -related characteristics on the going concern audit opinion. In addition, consistent with Habib's (2013) meta-analysis finding that the type of audit opinion decisions was negative only in non-US studies, rather than US studies, we stress that the results related to the factors influencing audit opinions are context-dependent. Hence, more related studies should be conducted in different contexts, especially in contexts where there is an evident paucity of related studies, such as developing African contexts. This is likely to reveal different factors that influence audit opinion, compared to these observed in developed and stable contexts. By investigating audit reporting in the Egyptian market, this study provides valuable insights to regulators and shareholders regarding the factors impacting audit opinions. This enhances their understanding of audit reporting in this context and contexts with similar socio-cultural nature. 
This study is not without limitations. The study sample is not a large one. This is due to the difficulty of data collection in developing countries, which is a common problem. In these countries, most data have to be collected manually. We suggest that the same idea can be applied in a developed context where stock markets and the audit industry are more stabilised and institutionalized than emerging economies. Then, the results of this study can be compared to our findings to know if/to what extent the results are context-depended. Besides, knowing that our data are related to the period before the current crisis of the COVID 19 pandemic that had tremendous effects on the economy worldwide, it is also suggested that future research can focus on the period affected by this crisis. We can then capture the pandemic's impacts by comparing the present findings to that future study's results. This can give further insights into the business/economic implications of the crisis, especially in the audit market.

\section{Acknowledgement}

The authors would like to thank Prince Sultan University for their support.

\section{References}

Abozaid, E. M., Elshaabany, M. M., and Diab, A. A. (2020) 'The impact of audit quality on narrative disclosure: Evidence from Egypt', Academy of Accounting and Financial Studies Journal, Vol. 24, No. 1, pp. 1-14.

Afify, H.A.E. (2009) 'Determinants of audit report lag: Does implementing corporate governance have any impact? Empirical evidence from Egypt', Journal of Applied Accounting Research, Vol. 10 No. 1, pp. 56-86.

Allgood, S. and Farrell, K.A. (2003) 'The match between CEO and firm', The Journal of Business, Vol. 76 No. 2, pp. 317-341.

Atwood, T.J., Drake, M.S., Myers, J.N. and Myers, L.A. (2011) "Do earnings reported under IFRS tell us more about future earnings and cash flows?”, Journal of Accounting and Public Policy, Vol. 30 No. 2, pp. 103-121.

Becker, C.L., Defond, M.L., Jiambalvo, J. and Subramanyam, K.R. (1998) "The effect of audit quality on earnings management", Contemporary Accounting Research, Vol. 15 No. 1, pp. 1-24.

Blay, A. D. (2005) 'Independence threats, litigation risk, and the auditor's decision process. Contemporary Accounting Research', Vol. 22, No. 4, pp. 759-789.

Breesch, D., \& Branson, J. (2009) 'The effects of auditor gender on audit quality'. IUP Journal of Accounting Research E Audit Practices, Vol. 8, No. 3/4, p78-107.

Bryan, D., Tiras, S. L., \& Wheatley, C. M. (200o, November) 'The relation of audit opinion and auditor change with bankruptcy emergence', In AAA Audit Section Midyear Meeting.

CAO (Central Auditing Organization) (2012) Auditing and Accounting, Retrieved from http://www.cao.gov.eg/ (Last accessed at 27/09/2013)

Carcello, Joseph V., Hermanson Dana R., Huss H. Fenwick (2000) 'Going-Concern Opinions: The Effects of Partner Compensation Plans and Client Size', AUDITING: A Journal of Practice, Vol. 19, No. 1, pp. 67-77.

Carcello, J. V., and Nagy, A. L. (2004) 'Audit firm tenure and fraudulent financial reporting', Auditing: a journal of practice \& theory, Vol. 23 No. 2, pp. 55-69.

Citron, D. B., and Taffler, R. J. (1992) 'The audit report under going concern uncertainties: an empirical analysis', Accounting and business research, Vol. 22 No. 88, pp. 337-345.

Craswell, A., Stokes, D. J., \& Laughton, J. (2002). Auditor independence and fee dependence. Journal of Accounting and Economics, Vol. 33, No. 2, pp. 253-275.

Daoud, K. A. A., Ismail, K., Izah, K. N., and Lode, N. A. (2014) 'The timeliness of financial reporting among Jordanian companies: do company and board characteristics, and audit opinion matter?', Asian Social Science, Vol. 10 No. 13, pp. 191-201.

DeAngelo, H.L. (1981) 'Auditor size and audit quality', Journal of Accounting and Economics, Vol. 3 No. 3, pp. 183199.

DeFond, M. L., and Lennox, C. S. (2011) 'The effect of SOX on small auditor exits and audit quality', Journal of Accounting and Economics, Vol. 52 No. 1, pp. 21-40.

EFSA (Egyptian Financial Supervisory Authority) (2012) Professional Accountants and Auditors, Retrieved from: http://www.efsa.gov.eg/content/efsa2_ar/efsa2_merge_page/auditors_merge_page.htm/ (Last accessed at 30/09/2013) 
El-Dyasty, M. M. (2017) 'Audit market in Egypt: An empirical analysis', [Online] Available at SSRN 3002783, (Accessed 23/7/2020).

Fan, J.H. and Wong, T.J. (2005) 'Do external auditors perform a corporate governance role in emerging markets? Evidence from East Asia', Journal of Accounting Research, Vol. 43 No. 1, pp. 35-72.

Gallizo Larraz, J. L., and Saladrigues Solé, R. (2016) 'An analysis of determinants of going concern audit opinion: Evidence from Spain stock exchange'. Intangible Capital, Vol. 12, No. 1, p. 1-16.

Habib, A. (2013) 'A meta-analysis of the determinants of modified audit opinion decisions', Managerial Auditing Journal. Vol. 28 No. 3, pp. 184-216.

Ireland, J. (2003) 'An empirical investigation of determinants of audit reports in the UK', Journal of Business Finance E Accounting, Vol. 30 No (7 \& 8), pp. 975-1015.

Jaggi, B., and Tsui, J. (1999) 'Determinants of audit report lag: Further evidence from Hong Kong', Accounting and business research, Vol. 30, No. 1, pp. 17-28.

Joe, J. R. (2003) 'Why press coverage of a client influences the audit opinion', Journal of Accounting Research, Vol. 41 No. 1, pp. 109-133.

Johl, S., Jubb, C. A., \& Houghton, K. A. (2007) 'Earnings management and the audit opinion: Evidence from Malaysia', Managerial Auditing Journal. Vol. 22 No. 7, pp. 688-715.

Kabir, M.H., Ainul, D.S. and Salat, I.A. (2012) 'Big 4 auditor affiliation and accruals quality in Bangladesh', Managerial Auditing Journal, Vol. 26 No. 2, pp. 161-181.

Karjalainen, J. (2011) 'Audit quality and cost of debt capital for private firms: Evidence from Finland', International journal of auditing, Vol. 15 No. 1, 88-108.

Kato, R., H. Semba, and Frendy. (2016) 'Influence of the audit market shift from big 4 to big 3 on audit firms' industry specialization and audit quality: Evidence from Japan', Academy of Accounting and Financial Studies Journal, Vol. 20 No. 3, pp.62-83.

Kaplan, S. E., and Williams, D. D. (2013) 'Do going concern audit reports protect auditors from litigation? A simultaneous equations approach', The Accounting Review, Vol. 88 No. 1, pp. 199-232.

Khlif, H., and Samaha, K. (2016) 'Audit committee activity and internal control quality in egypt', Managerial Auditing Journal. Vol. 31 No. 3, pp. 269-289.

Kumari, Prity, and Jamini Kanta Pattanayak (2017) 'Linking earnings management practices and corporate governance system with the firms' financial performance', Journal of Financial Crime, Vol. 24 No. 2, pp. 223241.

Krishnan, G. V., and Wang, C. (2015) 'The relation between managerial ability and audit fees and going concern opinions', Auditing: A Journal of Practice \& Theory, Vol. 34 No. 3, pp. 139-16o.

Li, C., Song, F. M., and Wong, S. M. (2008) 'A continuous relation between audit firm size and audit opinions: evidence from China', International Journal of Auditing, Vol. 12 No. 2, pp 111-127.

Lim, C.-Y. and Tan, H.-T. (2010) "Does auditor tenure improve audit quality? Moderating effects of industry specialization and fee dependence", Contemporary Accounting Research, Vol. 27 No. 3, pp. 923-957.

Lopez, T. J., Vandervelde, S. D., and Wu, Y. J. (2009) 'Investor perceptions of an auditor's adverse internal control opinion', Journal of Accounting and Public Policy, Vol. 28 No. 3, pp. 231-250.

Mareque, M., Rivo-López, E., Villanueva-Villar, M., and Lago-Peñas, S. (2019) 'Audit opinions: are they really different for family businesses?', SAGE Open, Vol. 9 No. 2, pp. 1-12.

McKeown, J. C., Mutchler, J. F., and Hopwood, W., (1991) 'Towards an explanation of auditor failure to modify the audit opinions of bankrupt companies', Auditing: A Journal of Practice and Theory, Vol. 10 (Supplement), pp. 1-13

Mohamed, D. M., and Habib, M. H. (2013) 'Auditor independence, audit quality and the mandatory auditor rotation in Egypt', Education, Business and Society: Contemporary Middle Eastern Issues, Vol. 6 No. 2, pp. 116-144.

Mutchler, Jane F., William Hopwood, and James M. McKeown (1997) "The influence of contrary information and mitigating factors on audit opinion decisions on bankrupt companies." Journal of Accounting research, Vol. 35, no. 2, pp. 295-310.

Ohlson, J. A. (1980) 'Financial ratios and the probabilistic prediction of bankruptcy', Journal of accounting research, Vol. 18, No. 1, 109-131.

Ruiz-Barbadillo, E., Gómez-Aguilar, N., De Fuentes-Barberá, C., \& García-Benau, M. A. (2004) 'Audit quality and the going-concern decision-making process: Spanish evidence', European Accounting Review, Vol. 13 No. 4, pp. 597-620.

Rusmin, R., and Evans, J. (2017) 'Audit quality and audit report lag: case of Indonesian listed companies', Asian Review of Accounting, Vol. 25 No. 2, pp. 191-210. 
Siregar, S. V., and Utama, S. (2008) 'Type of earnings management and the effect of ownership structure, firm size, and corporate-governance practices: Evidence from Indonesia', The international journal of accounting, Vol. 43 No. 1, pp. 1-27.

Tsipouridou, M., and Spathis, C. (2014) 'Audit opinion and earnings management: Evidence from Greece', Accounting Forum, Vol. 38, No. 1, pp. 38-54.

Vichitsarawong, T., and Pornupatham, S. (2015) 'Do audit opinions reflect earnings persistence?', Managerial Auditing Journal. Vol. 30 No. 3, pp. 244-276.

Wahdan, M., Spronck, P., Ali, H., Vaassen, E. and van den Herik, J. (2012) 'Auditing in Egypt: A study of the legal Framework and professional standards', [Online] Retrieved from http://citeseerx.ist.psu.edu/viewdoc/summary?doi=10.1.1.617.9533 (last accessed 23/7/2020)

Xie, Z., Cai, C., and Ye, J. (2010) 'Abnormal audit fees and audit opinion-Further evidence from China's capital market, China Journal of Accounting Research, Vol. 3, pp. 51-70.

$\mathrm{Xu}, \mathrm{H} ., \mathrm{Dao}, \mathrm{M}$. , and $\mathrm{Wu}, \mathrm{J}$. (2018) 'The effect of real activities manipulation on going concern audit opinions for financially distressed companies', Review of Accounting and Finance, Vol. 17 No. 4, pp. 514-539.

Yaşar, A., Yakut, E., and Gutnu, M. M. (2015) 'Predicting qualified audit opinions using financial ratios: Evidence from the Istanbul Stock Exchange’, International Journal of Business and Social Science, Vol. 6 No. 8, pp. 5767. 